Original Research Article

\title{
Cost variation analysis of various brands of topical eye preparations currently available in Indian pharmaceutical market
}

\author{
Shukrath Chandrappa, Kavitha Rajarathna*
}

Department of Pharmacology, Bangalore Medical College and Research Institute, KR Road, Bengaluru, Karnataka, India

Received: 17 September 2018 Accepted: 22 October 2018

*Correspondence to:

Dr. Kavitha Rajarathna, Email: kavitharajarathna@ gmail.com

Copyright: () the author(s), publisher and licensee Medip Academy. This is an openaccess article distributed under the terms of the Creative Commons Attribution NonCommercial License, which permits unrestricted noncommercial use, distribution, and reproduction in any medium, provided the original work is properly cited.

\begin{abstract}
Background: Ocular drug delivery is a complex drug delivery system, and topical administration being the most frequently employed route of drug delivery in eye diseases. Many topical eye preparations are sold under brand names. The variation in the costs of the same drug and inadequate information on quality and bio-equivalence makes it difficult for the physician to prescribe the most costeffective treatment. The objective of this study was to analyse the cost variation in different brands of commonly used topical eye preparations in India.

Methods: The minimum and the maximum cost in Rupees (INR) of particular topical eye preparations manufactured by various pharmaceutical companies in the same strength were noted. The percentage cost variation and cost ratio were calculated for each brand.

Results: The costs of the total of 19 topical eye preparations available in 26 different formulations in India were analysed and a substantial variation in cost was observed. Of 19 drug formulations studied, the percentage cost variation of 10 drug formulations was more than $100 \%$ out of which one had more than $1000 \%$ variation. Cost ratio was also observed to be very high and 10 drug formulations had this ratio more than two.

Conclusions: There is a wide variation in the prices of different brands, so there is an urgent need to raise the awareness of physicians about cost variation to lower the financial burden on patients.
\end{abstract}

Keywords: Cost analysis, Cost variation, Eye drops, Pharmacoeconomics

\section{INTRODUCTION}

Effective treatment of ocular diseases is a formidable task because of the nature of diseases and presence of ocular barriers. Ocular drug delivery is complex since delivery of drugs to the targeted ocular tissues is restricted by precorneal and other ocular barriers. Advances in drug delivery techniques have revolutionized the ocular drug delivery, but the topical administration is the most employed route of drug delivery in ocular diseases. ${ }^{1}$

The pharmaceutical market in India has more than 20,000 drug formulations where most of them are sold under brand names. ${ }^{2}$ There is a considerable variation in drug costs that creates problems for both the patient as well as the prescriber. ${ }^{3}$ The large variation in the costs of the same drug with insufficient information on quality and bioequivalence makes it difficult for the physician to prescribe the most cost-effective treatment. ${ }^{2,3}$

One of the main reason for the patients to go-off regimen is the cost of drugs. ${ }^{4}$ Unlike developed countries, the majority of the population in India, are still not covered under medical insurance, so affordability becomes a major concern. ${ }^{5,6}$ To address such situations, the Government of India has taken measures like establishing the National Pharmaceutical Pricing Authority and drug price control 
order (DPCO). However, only a few drugs were included in DPCO. It was noted that the percentage rise in the price of drugs under DPCO was less than the drugs that are not under its purview. ${ }^{7,8}$

Information generated from cost variation analysis studies will be useful for both, the doctors in choosing the proper drug for their patients and for the policymakers in effectively utilizing the few resources that are available. ${ }^{9}$ This study was undertaken to compare the cost of drugs of the different brand of topical ophthalmic drugs as very few studies are available in the Indian scenario.

\section{METHODS}

The cost of particular topical eye preparations in the same dose and dosage forms being manufactured by different companies was compared using "Current Index of Medical Specialties" (CIMS) April - July 2018 in this descriptive study. ${ }^{10}$ The cost was expressed in Indian rupee (INR) per the standard dose/ concentration and quantity of each topical preparation. The cost information of all the topical eye preparations mentioned in the CIMS April - July 2018 was recorded. The drugs manufactured by only one pharmaceutical company or by different pharmaceutical companies of different strengths were excluded. Drugs were categorized into anti-infectives and antiseptics, topical corticosteroids, mydriatics, anti-glaucoma drugs, anti-inflamatories, and lubricants. The cost information of each drug like, maximum cost and minimum cost among various brands and number of manufacturing pharmaceutical companies were collected.

The difference between the maximum and minimum costs of the same drug manufactured by different pharmaceutical companies was calculated. The cost ratio, the ratio of the highest cost brand to lowest cost brand of the same generic topical eye preparations was calculated.

The following formula was used to calculate the percentage cost variation,

Cost variation $(\%)=$

(Maximum cost - Minimum cost) $\times 100$

Minimum cost.

\section{Statistical analysis}

The data collected was entered in Microsoft excel 2007 and analysed for percentage cost variation and cost ratio of the individual drugs. The findings were expressed as absolute numbers as well as percentage.

\section{RESULTS}

The costs of a total of nineteen topical eye preparations available in twenty-six different formulations were analysed and a substantial variation in cost was observed.
Of the 19 drug formulations, 10 were anti - infective's and antiseptics, 2 were topical corticosteroids, 2 were mydriatics, 4 were anti- glaucoma drugs, and 1 was anti inflamatories (Table 1). Among anti - infectives and antiseptics, 10 brands were available for moxifloxacin $0.50 \%$ eye drops and 16 brands for ofloxacin $0.30 \%$ eye drops, and all other preparations were available in less than ten different brands. Of the 19 drug formulations studied, the percentage cost variation of 10 drug formulations was more than $100 \%$, out of which one formulation had more than $1000 \%$ variation. Cost ratio of 10 drug formulations were more than two.

Moxifloxacin $0.5 \%$ eye drops had maximum percentage cost variation of $5610.66 \%$ and cost ratio of 57.11 , followed by ofloxacin $0.30 \%$ eye drops $(310.92 \%, 4.11)$, timolol $0.50 \%$ eye drops $(263.64 \%, 3.64)$, ciprofloxacin $0.30 \%$ eye drops $(142.42 \%, 2.42)$, tobramycin $0.30 \%$ eye drops $(120.14 \%, 2.20)$. The Fixed Dose Combination (FDC) of tropicamide $0.8 \%+$ phenylephrine $\mathrm{HCl} 5 \%$ eye drops had minimum percentage cost variation of $42 \%$ and a cost ratio of 1.42 . The cost ratio and percentage cost variation of other formulations are mentioned in Table 1 and in Figure 1.

Among anti - infectives and antiseptics, Moxifloxacin $0.5 \%$ eye drops, ofloxacin $0.30 \%$ eye drops, tobramycin $0.30 \%$ eye drops were having cost ratio of more than 2 . Fluoromethane $0.10 \%$ eye drops in topical corticosteroid group, timolol $0.50 \%$ eye drops and latanoprost $50 \mathrm{mcg} / \mathrm{ml}$ eye drops among anti glaucoma drugs, cromoglycic acid $2 \%$ eye drops among anti inflamatories were also having cost ratio of more than 2 . The average percentage cost ratio of anti - infectives was $522.64 \%$, followed by lubricants $(134.31 \%)$, topical corticosteroids $(96.84 \%)$, anti glaucoma drugs $(91.57 \%)$, anti - inflamatories $(58.46 \%)$, and mydriatics $(30.1 \%)$ (Figure 1).

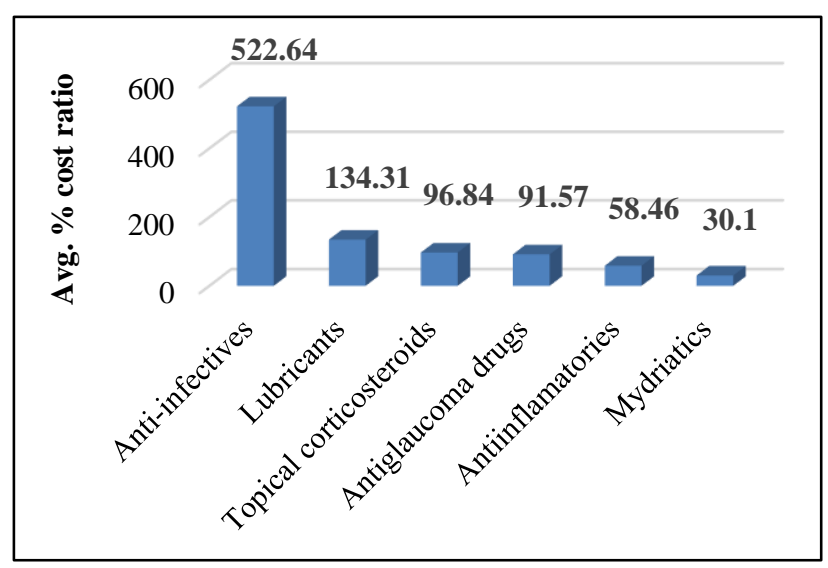

Figure 1: Maximum price variability (percentage) among various categories of topical eye preparations.

\section{DISCUSSION}

Medication compliance is more important in chronic eye disorders like glaucoma, chronic conjunctivitis etc, and the 
cost of the prescribed drugs is one of the factors which decide drug compliance. ${ }^{11,12}$ The present study showed a wide variation in the price of topical eye preparations across the different brands available in the Indian market. In a cost variation study done on antiglaucoma drugs by Jadhao $\mathrm{T}$ et al, showed wide variation in cost and latanoprost eye drops showed maximum variation among eye drops which is in consistent with the findings of the present study. ${ }^{13}$ It is evident from the Table that, price variation is large when numbers of manufacturing companies are more. There are many branded formulations of a generic drug molecule, this creates confusion among consumers, and often these consumers got mislead by unfair traders. Among topical eye preparations, antiinfectives had shown maximum price variation, as more number of companies is marketing it.

Table 1: Cost variation among various brands of topical eye preparations.

\begin{tabular}{|c|c|c|c|c|c|}
\hline Drug & Dosage form & Dose (mg) & $\begin{array}{l}\text { Cost range } \\
\text { (INR)* }\end{array}$ & Cost ratio & $\begin{array}{l}\text { Price } \\
\text { variation }\end{array}$ \\
\hline \multicolumn{6}{|l|}{ Anti-infectives and antiseptics } \\
\hline Acyclovir & Eye ointment & $3 \%$ & $37.04-55.5$ & 1.50 & 49.84 \\
\hline Ciprofloxacin & Eye drops & $0.30 \%$ & $6.53-15.83$ & 2.42 & 142.42 \\
\hline Gatifloxacin & Eye drops & $3 \%$ & $25.06-48.46$ & 1.93 & 93.38 \\
\hline Gentamicin & Eye drops & $0.30 \%$ & $7.65-12.5$ & 1.63 & 63.40 \\
\hline Levofloxacin & Eye drops & $0.50 \%$ & $19.75-37.8$ & 1.91 & 91.39 \\
\hline \multirow{2}{*}{ Moxifloxacin } & Eye drops & $0.50 \%$ & $39.4-2250$ & 57.11 & 5610.66 \\
\hline & Eye ointment & $0.50 \%$ & $44.7-65$ & 1.45 & 45.41 \\
\hline Natamycin & Eye drops & $5 \%$ & $76.3-85.87$ & 1.13 & 12.54 \\
\hline Ofloxacin & Eye drops & $0.30 \%$ & $17.95-73.76$ & 4.11 & 310.92 \\
\hline \multirow{3}{*}{ Sulphacetamide } & Eye drops & $10 \%$ & $11-21$ & 1.91 & 90.91 \\
\hline & Eye drops & $20 \%$ & $12-23$ & 1.92 & 91.67 \\
\hline & Eye drops & $30 \%$ & $13.4-23$ & 1.72 & 71.64 \\
\hline Tobramicin & Eye drops & $0.30 \%$ & $39.52-87$ & 2.20 & 120.14 \\
\hline \multicolumn{6}{|l|}{ Topical corticosteroids } \\
\hline Fluorometholone & Eye drops & $0.10 \%$ & $38.5-79$ & 2.05 & 105.19 \\
\hline $\begin{array}{l}\text { Ciprofloxacin + } \\
\text { dexamethasone }\end{array}$ & Eye drops & $0.3 \%+0.1 \%$ & $10.08-19$ & 1.88 & 88.49 \\
\hline \multicolumn{6}{|l|}{ Mydriatics } \\
\hline Cyclopentolate & Eye drops & $1 \%$ & $19.99-29.7$ & 1.49 & 48.57 \\
\hline $\begin{array}{l}\text { Tropicamide + phenylephrine } \\
\text { hcl }\end{array}$ & Eye drops & $0.8 \%+5 \%$ & $43-48$ & 1.12 & 11.63 \\
\hline \multicolumn{6}{|l|}{ Anti-glaucoma drugs } \\
\hline \multirow{2}{*}{ Brimonidine } & Eye drops & $0.20 \%$ & $107.27-186.28$ & 1.74 & 73.66 \\
\hline & Eye drops & $0.15 \%$ & $154-210.16$ & 1.36 & 36.47 \\
\hline Latanoprost & Eye drops & $50 \mathrm{mcg} / \mathrm{ml}$ & $199-401$ & 2.02 & 101.51 \\
\hline Pilocarpine & Eye drops & $2 \%$ & $32.65-51.3$ & 1.57 & 57.12 \\
\hline \multirow{2}{*}{ Timolol } & Eye drops & $0.25 \%$ & $17-19.9$ & 1.17 & 17.06 \\
\hline & Eye drops & $0.50 \%$ & $22-80$ & 3.64 & 263.64 \\
\hline \multicolumn{6}{|l|}{ Anti-inflamatories } \\
\hline \multirow{2}{*}{ Cromoglycic acid } & Eye drops & $2 \%$ & $33.5-70.42$ & 2.10 & 110.21 \\
\hline & Eye drops & $4 \%$ & $41-58$ & 1.41 & 41.46 \\
\hline Diclofenac & Eye drops & $0.10 \%$ & $15.1-20.97$ & 1.39 & 38.87 \\
\hline Ketorolac & Eye drops & $0.50 \%$ & $28.5-46$ & 1.61 & 61.40 \\
\hline Olopatidine & Eye drops & $0.10 \%$ & $62.2-77$ & 1.24 & 23.79 \\
\hline Flurbiprofen & Eye drops & $0.03 \%$ & $20-35$ & 1.75 & 75.00 \\
\hline \multicolumn{6}{|l|}{ Lubricants } \\
\hline Povidone + polyvinyl alcohol & Eye drops & $6 \%+1.4 \%$ & $37.6-64$ & 1.70 & 70.21 \\
\hline Carboxy methylcellulose & Eye drops & $0.50 \%$ & $60-88$ & 1.47 & 46.67 \\
\hline \multirow{2}{*}{$\begin{array}{l}\text { Sodium carboxy } \\
\text { methylcellulose }\end{array}$} & Eye drops & $0.50 \%$ & $70-195$ & 2.79 & 178.57 \\
\hline & Eye drops & $1 \%$ & $122-417$ & 3.42 & 241.80 \\
\hline
\end{tabular}


Health insurance in India principally covers hospitalization and not out-patient or domiciliary care. Out-patient healthcare spending in India has augmented by almost fifty percent in the last 10 years. Most of the topical eye preparations are prescribed on an out-patient basis. It increases "out of pocket spending" from patients and this may affect drug compliance and add to the cost of the drug making it difficult to reach a broad fraction of the population. ${ }^{14}$

According to prescribing pattern studies, prescribing with the brand name is more prevalent. ${ }^{15}$ Prescribing by generic names gives flexibility to the patient in choosing the brand which they can afford since generic drugs are in no way inferior to the costlier branded counterpart. ${ }^{15}$ So there is an urgent need to create awareness among the health care providers regarding cost variation and its related consequences. The DPCO has to take more drugs into consideration for price control.

The limitation of the study is that sources of information were limited to CIMS but there are few other brands which are marketed in India but not published in the abovementioned source.

\section{CONCLUSION}

There is a significant variation in the price of various topical eye preparations. As most of the preparations being prescribed on an out-patient basis, which was not covered under most of the insurance program. Out of pocket expenditure adversely affects the drug compliance in the long run. There should be a comprehensive action from policymakers, regulatory authorities, government agencies, doctors, pharmacists, and the general public to solve this issue of cost variation of drugs.

\section{ACKNOWLEDGEMENTS}

Authors would like to thank the faculties and post graduate students of Department of Pharmacology of Bangalore Medical College and Research Institute, Bengaluru, India for their support in conducting the study.

Funding: No funding sources

Conflict of interest: None declared

Ethical approval: Not required

\section{REFERENCES}

1. Rawas-Qalaji M, Williams CA. Advances in ocular drug delivery. Curr Eye Res. 2012;37(5):345-56.

2. Kolasani BP, Malathi DC, Ponnaluri RR. Variation of Cost among Anti-cancer Drugs Available in Indian Market. J Clin Diagn Res. 2016;10(11):FC17-FC20.
3. Akila L, Rani RJ. Cost analysis of different brands of antianginal drugs available in India. Int J Basic Clin Pharmacol. 2015;4(5):860-3.

4. Mishra S, Gioia D, Childress S, Barnet B, Webster RL. Adherence to medication regimens among lowincome patients with multiple comorbid chronic conditions. Health Soc Work. 2011 Nov; 36(4):24958 .

5. Jana S, Mondal P. Pharmacoeconomics: the need to sensitize undergraduate medical students. Indian J Pharmacol. 2005;37(5):277-8.

6. Chawan VS, Gawand KV, Badwane SV. Cost analysis of oral hypolipidemic agents available in India. Int $\mathbf{J}$ Basic Clin Pharmacol. 2014;3(6):954-7.

7. Kumar V, Gupta NV, Kumar KA. A comparison between old and latest systems in DPCO. Int J Pharm Pharmaceut Sci. 2014;6(2):19-20.

8. Compendium of notified ceiling prices of scheduled drugs- NPPA; 2015. Available at: http://www.nppaindia.nic.in/ceiling price. Accessed 12 Aug 2018.

9. Kuruvilla A, George K, Rajaratnam A, John KR. Prescription patterns and cost analysis of drugs in a base hospital in south India. Natl Med J India. 1994;7(4):167-8.

10. Current Index of Medical Specialties, April - July 2018:199-206.

11. Muir KW, Lee PP. Glaucoma Medication Adherence: Room for Improvement in Both Performance and Measurement. Arch Ophthalmol. 2011 Feb; 129(2):243-5.

12. Brown MT, Bussell JK. Medication Adherence: WHO Cares? Mayo Clin Proc. 2011 Apr; 86(4):304-14.

13. Jadhao $\mathrm{T}$, Advani $\mathrm{M}$, Jamdade $\mathrm{S}$. Cost variation analysis of antiglaucoma drugs available in Indian market. Paripex Indian J Res. 2018 Feb 14;6(2).

14. Sohn HS, Kwon J, Park E. Out-of-Pocket (OOP) Expenditure for Prescription Drugs among South Korean Outpatients under the National Health Insurance System: Focus on Chronic Diseases Including Diabetes. J Diabetes Metab. 2012;3(5):197.

15. Tiwari A, Reddy P, Goyal C. Cost analysis of antifungal drugs available in India: A pharmacoeconomic perspective. Indian J Pharmacy Pharmacol. 2016;3(4):192-6.

Cite this article as: Chandrappa S, Rajarathna K. Cost variation analysis of various brands of topical eye preparations currently available in Indian pharmaceutical market. Int J Basic Clin Pharmacol 2018;7:2364-7. 